\title{
MAST CELLS OF THE OMENTUM IN RELATION TO STATES OF ADRENOCORTICAL DEFICIENCY AND EXCESS*
}

\author{
By Burton L. Baker \\ Deparment of Anatomy, University of Michigan Medical School, Ann Arbor, Michigan
}

Little is known of the function of several components of loose fibroelastic connective tissue, the mast cells, in particular, having been resistant to experimental attack. Nevertheless, a discussion of them is appropriate to a conference on mechanisms of adrenocortical hormone action for several reasons. First, it is generally agreed that mast cells contain a mucopolysaccharide that, according to Lison ${ }^{16}$ and Holmgren and Wilander, ${ }^{14}$ stains metachromatically because of its esterification with sulfuric acid, the latter investigators concluding that this substance is heparin. Asboe-Hansen ${ }^{3}$ reports that injection of corticotropin into man causes a marked reduction in the number of mast cells. Others claim that the coagulation time may be reduced ${ }^{10}$ or prolonged, with an increase in the quantity of circulating heparin-like substances, ${ }^{18}$ during treatment of human patients with corticotropin or cortisone. These effects require further study, however, because of the wide variation in the values obtained by the technical methods employed. ${ }^{12}$

Second, other workers believe that mast cells produce the mucopolysaccharide hyaluronic acid, which is an important constituent of the ground substance in connective tissue. Although not all histologists share this viewpoint, considerable inferential evidence may be marshalled to support it. Mast cells accumulate in the dermis bordering areas of epidermal hyperplasia resulting from applications of carcinogens to mouse skin. Cramer and Simpson ${ }^{11}$ regard this occurrence as a possible protective action on the part of mast cells to supplement the hyaluronic acid of the dermal ground substance. The frequency of mast cells in myxedematous skin suggests to Asboe-Hansen ${ }^{2}$ that they are the source of the increased amount of hyaluronic acid appearing in the dermis. He postulates that adrenocortical hormones may relieve inflammatory processes by reducing the capacity of mast cells to accelerate their production of hyaluronic acid. ${ }^{3}$ Sylvén ${ }^{19}$ holds that mast cells secrete the ground substance of granulation tissue. If this hypothesis is correct, mast cells merit consideration in experiments concerned with the effect of adrenocortical secretion on mesenchyme or fibroelastic connective tissue, because ground substance is one of the three constant components.

Third, mast cells are found with variable frequency in the connective tissue sheath of blood vessels, including small arteries (FIGURE 7 ), venules, and capillaries. If the hypothesis is correct that mast cells secrete ground substance, then it is conceivable that they may modify vascular permeability by altering the state of the mucopolysaccharides encompassing vascular endothelium. The irregularity of their occurrence would seem to militate against this possibility, however. Since so much evidence indicates that adrenocortical steroids

* This investigation was supported (in part) by a research grant (A-131) from the National Institutes of Health and grants from Merck and Co. and the Upjohm Company. 
aid in regulating the walls of blood vessels, determination of the changes that occur in mast cells in varying states of permeability appears to be worthwhile.

Finally, current information concerning the relationship of adrenocortical secretions to mast cells is conflicting and indefinite. According to Cavallero and Braccini ${ }^{9}$ cortisone reduces the number of mast cells in sections of skin, muscle, and myocardium of the rat. Kelsall and $\mathrm{Crabb}^{15}$ counted the number of mast cells per cross section of the thymus of hamsters treated with adrenocortical extract or cortisone. Their results are inconclusive because of the marked atrophy of the thymus which occurs under this treatment. The number of mast cells appears to be less than in ad libitum-fed controls but more than in inanition controls. Baker et al. ${ }^{5}$ noted an increase in the concentration of mast cells in the thymic capsule of rats treated with corticotropin but regarded this outcome as secondary to the reduction in size of the thymus rather than resulting from a real increase in number. The need for more definite information on the relationship of the adrenal cortex to mast cells is emphasized by the dramatic regression of mastocytoma in one cortisone-treated dog recently reported by Bloom. ${ }^{7}$

This paper deals with the numerical and morphological variations which occur in mast cells when the concentration of circulating adrenocortical hormones is deficient or excessive.

Experimental Method. Precise study of mast cells is complicated by a dearth of knowledge as to their origin, a great normal variation in number, by the unusual fragility of the cell, and by the solubility in water of cytoplasmic constituents. To obviate at least the latter two complications, the observations to be reported were made on air-dried spreads of the omentum of rats that were stained by the May-Gruenwald-Giemsa procedure.

Mast cells are scattered throughout the omentum of the rat, including the fat that surrounds the larger blood vessels. They appear in greatest number in the milk spots and in the connective-tissue-surrounding capillaries, small arteries, and venules. Because of this positional relationship to capillaries, the number of mast cells is frequently great in the capillary network that borders the omental fat. Special attention will be directed to the effect of adrenocortical hormones on mast cells located alongside capillaries in avascular areas of the omentum, in milk spots, and at the edge of mesenteric fat. Examination of these different sites is necessary because mast cells migrate by amoeboid movement ${ }^{17}$ and might change their location under the influence of hormones.

The mast cells bordering the omental capillaries (approximately 13-32 $\mu$ in diameter) were counted in each high-power view or $350 \mu$ lengthwise section of the vessel an average of 32 sections being studied per animal. The mast cells of the avascular omental regions were ascertained by a differential count of the different types of cells that compose the omentum, over 1000 cells being counted per specimen.

\section{The Effect of Adrenalectomy}

If the normal morphology and number of mast cells is maintained by the level of circulating adrenocortical steroids, some change should be observed 
after adrenalectomy. Accordingly, adult male Sprague-Dawley rats were adrenalectomized and allowed to live 21-43 days before autopsy. The individual control animals of six adrenalectomized rats were pair-fed, while those of 11 adrenalectomized rats ate ad libitum. The latter 11 pairs of rats were given 4 cc. of 0.9 per cent $\mathrm{NaCl}$ intraperitoneally two hours before autopsy in connection with another experiment. This treatment with salt solution did not affect the mast cells. All adrenalectomized rats were maintained on a 1 per cent solution of $\mathrm{NaCl}$ as drinking fluid.

TABIE 1 shows that, following adrenalectomy, the paravascular mast cells increased slightly in number per unit length of capillary. Although this increase is small, it is obtained rather consistently. The number of mast cells was greater in the adrenalectomized member of five of six pairs whose food intake was the same as that of its control, and in 9 of 11 that ate ad libitum.

The small difference in the percentage of mast cells in avascular omental areas in adrenalectomized and control rats (1.3 and 1.7 per cent respectively)

TABLE 1

The Ermet of Adrenalectomy on the Mean Number of Mast Cells

\begin{tabular}{|c|c|c|c|c|}
\hline & No. rats & Days adx. & $\begin{array}{l}\text { No./unit length } \\
\text { of cap. }\end{array}$ & $\begin{array}{l}\text { Per cent in } \\
\text { avascular areas }\end{array}$ \\
\hline $\begin{array}{l}\text { Adrenalectomy } \\
\text { Pair-fed controls }\end{array}$ & $\begin{array}{l}6 \\
6\end{array}$ & $\stackrel{24-43}{-}$ & $\begin{array}{l}4.7 \pm 0.8^{*} \\
3.2 \pm 1.2\end{array}$ & $\begin{array}{l}1.3 \pm 0.5 \\
1.7 \pm 1.2\end{array}$ \\
\hline $\begin{array}{l}\text { Adrenalectomy } \\
\text { Ad lib., controls }\end{array}$ & $\begin{array}{l}11 \\
11\end{array}$ & $\stackrel{7-41}{-}$ & $\begin{array}{l}7.4 \pm 3.5 \\
5.5 \pm 2.7\end{array}$ & \\
\hline
\end{tabular}

* Standard deviation.

is of little significance because of the great variation in number and occurrence of fewer mast cells in only four of six operated rats.

The milk spots located in the fat surrounding the larger omental blood vessels were denser and more numerous per unit area in a majority of adrenalectomized rats and, frequently, the mast cells in them were more plentiful. Likewise, mast cells were more concentrated in the vascular network of the edge of omental fat (FIGURes 1 and 2). Evaluation of this change is difficult because omental fat was depleted consistently after adrenalectomy, with the possible result that mast cells were dispersed less widely. The blood vessels in omental fat were much wider in adrenalectomized than in control animals. This may have been due to a reduced tonicity of the vessel walls, the necessity for an increase in blood flow concomitant with a higher rate of metabolism in adipose tissue or the milk spots they supply, or a reduced external pressure resulting from resorption of depot fat, which would allow the vessels to assume a more normal caliber.

No variations in size or general morphology of mast cells occurred after adrenalectomy. Thus adrenalectomy appears to have little effect on omental mast cells of the rat, only a small increase in number bordering the capillaries being indicated. 


\section{The Effect of Hydrocortisone}

Eight pairs of adult male Sprague-Dawley rats were used. One of each pair received $3 \mathrm{mg}$. of hydrocortisone (17-hydroxycorticosterone)* suspension daily for 10 days, the food intake of the control being limited to that of the hormone-treated rat. Four rats received the hormone suspended in 10 per cent ethanol and four received the hormone suspended in 0.9 per cent $\mathrm{NaCl}$ to which two small drops of Tween 80 were added per $20 \mathrm{cc}$. of fluid. Control animals were given the suspending medium.

No change occurred in the number of mast cells per unit length of blood vessel as a result of the action of hydrocortisone (TABLE 2). In seven of eight cases, hydrocortisone produced an increase in the percentage of mast cells in avascular areas with the difference of the means being small (1.65 per cent as compared with 1.17 for the controls). This does not indicate an absolute increase in number of mast cells because eosinophiles, lymphocytes and, to a

TABLE 2

The Efyect of Hydrocortisone on Body Weight and Mean Number of Mast Cells iN THE OMENTUM

\begin{tabular}{c|c|c|c|c}
\hline \multicolumn{1}{c|}{ Treatment } & No. rats & $\begin{array}{c}\text { Mean per cent loss } \\
\text { body weight }\end{array}$ & $\begin{array}{c}\text { No. mast cells/unit } \\
\text { length of cap. }\end{array}$ & $\begin{array}{c}\text { Per cent mast cells } \\
\text { in avascular areas }\end{array}$ \\
\cline { 1 - 3 } $\begin{array}{l}\text { Hydrocortisone } \\
\text { Controls } \dagger\end{array}$ & 8 & $19.5 \pm 3.8^{*}$ & $5.2 \pm 1.4$ & $1.65 \pm 0.53$ \\
\hline
\end{tabular}

* Standard deviation.

+ Pair-fed.

slight degree, the fibroblasts, all dropped in percentage under treatment with hydrocortisone.

Hydrocortisone had the reverse effect of adrenalectomy in the regions of omental fat, the amount of fat being increased and in some instances, the milk spots reduced in size. Mast cells were less concentrated at the edge of the omental fat, but this was probably due to greater dispersion resulting from the increased fat (FIGURES 3 and 4). Hydrocortisone, under these conditions, appears to have no effect on the number or morphology of omental mast cells.

The Effect of Cortisone on the Early Inflammatory Reaction Induced by Peptone

In order to study the participation of mast cells in the early vascular inflammatory reaction, adult male rats were adrenalectomized and, after 7 days, 4 cc. of a sterile 5 per cent peptone solution was injected intraperitoneally. Half of the rats received subcutaneously $5 \mathrm{mg}$. $(1 \mathrm{cc}$.) doses of cortisone suspended in 10 per cent ethanol one hour prior to the peptone injection; simultaneously with it, and 3 hours after it; a total of $15 \mathrm{mg}$. being administered to each rat. Controls were given 10 per cent ethanol in place of the cortisone. The omenta were removed for study six hours after the peptone injection.

The intravenous administration of peptone to dogs causes a degranulation

* We wish to express our appreciation to Dr. Elmer Alnert of Merck and Co. Inc., for the hydrocortisone and cortisone he supplied for these studies. 
of mast cells in the liver and spleen but does not affect significantly those in the lungs. ${ }^{21}$ The introduction of foreign protein (albumen) into the abdominal cavity of the rat has been reported to cause a disappearance of mast cells from the omentum. ${ }^{20}$ In our experiments, we desired to study the response of mast cells to intra-abdominally administered foreign protein, particularly with respect to concurrent vascular changes and the presence of varying levels of circulating adrenocortical steroids.

Within six hours after the introduction of 5 per cent peptone into the abdominal cavity of the rat, some mast cells apparently release part of their cytoplasm, liberating the contained granules into the surrounding connectivetissue matrix. In the immediate vicinity of these mast cells, stellate and round cells appear, which contain sparse, blue granules. One might assume that they represent newly forming mast cells or phagocytic cells that have engulfed the liberated mast cell granules. The latter explanation seems to be more tenable. This response typifies the mast cells located in avascular areas of the omentum but more strikingly those along blood vessels. In the latter location, phagocytosis of mast cell granules by stellate clasmatocytes is unusually common. Cortisone failed to protect mast cells from loss of granules and also did not modify significantly the uptake of release granules by paravascular clasmatocytes (FIGUREs 5 and 6). Nevertheless, cortisone exerted a profound effect in reducing the amount of congestion of the small blood vessels and the magnitude of polymorphonuclear leucocytic migration out of the capillaries. Thus, with this experimental procedure, there was a clear-cut effect by cortisone on the capillary wall and the capacity of leucocytes to move through it, without any modification in the response of mast cells to peptone being detected. Therefore, it appears that, in this early type of inflammation, cortisone modifies the capillary wall without the apparent participation of mast cells. This conclusion is suggested further by the irregular occurrence of mast cells along these vessels.

\section{Correlative Comments}

These observations suggest that adrenalectomy and administration of hydrocortisone do not have a marked effect on the mast cells of the rat omentum, although a small increase in number of those located along blood vessels was indicated after adrenalectomy. Some reconciliation of these observations with those of Cavallero and Braccini ${ }^{9}$ should be sought, since these workers found that cortisone acetate reduces the number of mast cells in skin, myocardium, and muscle of the rat. In their experiments, no account was taken of the difference in food intake between treated and control animals. At present, it is not known how much this factor could have modified their results.

Second, higher doses of cortisone were administered for shorter periods of time (10 mg. for three days) and lower doses for longer periods (up to 70 days) than were employed in our experiments. Also, Bloom ${ }^{7}$ employed the rather high dose of $100 \mathrm{mg}$. of cortisone per day in order to induce regression of canine mastocytoma.

Third, there is no proof that mast cells in all parts of the body perform the 
same function. Indeed, some evidence indicates that the mast cells of various locations differ in their reaction to experimental procedures. The omental mast cells may be more resistant to adrenocortical hormones than those in myocardium or skin. Local treatment of rat skin with adrenocortical hormones (extract or cortisone) causes a reduction in size, granulation, and number of mast cells in the dermal reticular layer in the area of application but they remain unchanged outside of the treated area. The mast cells located just beneath the epidermis are affected most severely. This change is obvious upon cursory examination of sections of skin. The magnitude of reduction is shown by TABLE 3 , which gives the number of mast cells observed in the dermis of the right and left sides of the neck of rats, the right side having been treated daily with $100 \mu \mathrm{g}$. of cortisone $(0.1 \mathrm{cc}$.) in 25 per cent alcohol for 133 days, the controls receiving equal volumes of the solvent. The number of mast cells was determined in strips $350 \mu$ wide extending from the epidermis into the inner border of the portion of the dermis that contains elastic fibers. Since only collagenous fibers are reduced by the hormone, the extent of elastic fibers

TABLE 3

The Effect of Local Treatment with Cortisone on the Number of Mast Cells in the Dermis

\begin{tabular}{l|c|c|c}
\multirow{2}{*}{ Treatment } & \multicolumn{2}{|c|}{ Mean no./unit area } & $\begin{array}{c}\text { Mean \% reduction } \\
\text { treated side }\end{array}$ \\
\cline { 2 - 4 } & Treated side & Nontreated side & \\
\hline Cortisone & $1.4 \pm 1.0^{*}$ & $3.8 \pm 1.4$ & 64.5 \\
$25 \%$ Alcohol & $3.3 \pm 1.5$ & $3.6 \pm 1.4$ & 4.0 \\
\hline
\end{tabular}

* Standard deviation.

outlined a comparable amount of dermis in both treated and nontreated skins. The specimens were stained with Gomori's aldehyde-fuchsin procedure which reveals both mast cells and elastic fibers. Cortisone caused a 64.5 per cent reduction in number whereas alcohol reduced them only 4 per cent.

It must be remembered that prolonged local treatment of the skin with adrenocortical steroids will induce far more profound structural modification of the dermis than can be elicited by systemic administration of either cortisone or corticotropin. One is led to the supposition that, when mast cells are reduced by cortisone, the effect is a manifestation of exaggerated physiological action due to great overdosage.

The hypothesis that mast cells secrete a component of the ground substance should be weighed against the possibility that fibroblasts perform this function. Several observations of the behavior of fibroblasts in states of local or systemic hyper-adrenocorticalism indicate that their activity is suppressed. They remain small and fail to proliferate at a normal rate in the formation of granulation tissue.1. 6 Concurrently, the local accelerated spreading action of hyaluronidase, which typifies the skin of these rats, could result from retarded production of hyaluronic acid by the fibroblasts. ${ }^{13}$ When the number of mast cells is reduced in rat skin treated locally with adrenal steroid hormones, the fibroblasts are affected similarly. 
It is hoped that the negative viewpoint expressed in this presentation with respect to the effect of adrenal hormones on mast cells will not discourage other investigators from studying them further. The experimental methods we and others have employed are not sufficiently varied to permit a final conclusion concerning the participation of mast cells in the induction of adrenocortical hormone effects. Nevertheless, the current enthusiasm for mast cells as the site of formation of ground substance should not cause us to ignore the other leading candidate for the honor-the fibroblast.

\section{References}

1. Alrich, E. M., J. P. Carter, \& E. P. Lemman. 1951. Ann. Surg. 133: 783.

2. Asboe-Hansen, G. 1950. Bull. hist. appl. physiol, et tech microscop. 27: 5.

3. Asboz-Hansen, G. 1950. Scand. J. Clin. \& Lab. Invest. 2: 271.

4. BAKER, B. L. 1952. Recent Progress Hormone Res. 7: 331.

5. Baker, B. L., D. J. Ingle, \& C. H. LI. 1951. Am. J. Anat. 88: 313.

6. Baker, B. L., \& W. L. Whitaker. 1950. Endocrinology. 46: 544.

7. BLOOM, F. 1952. Proc. Soc, Expll. Biol. Med. 79: 651.

8. CAstor, C. W., \& B. L. BaKer. 1950. Endocrinology. 47: 234.

9. Cavallero, C., \& C. Braccini. 1951. Proc. Soc. Exptl. Biol. Med. 78: 141.

10. Cosgriff, S. W., A. F. Difrenbach, \& W. Vogt, JR. 1950. Am. J. Med. 9: 752.

11. Cramer, W., \& W. L. Simpson. 1944. Cancer Research. 4: 601.

12. Friedman, I. A., S. O. Schwartz, \& M. Vincenti. 1952. J. Am. Med. Assoc. 150: 83.

13. Hayes, M. A., T. G. Reed, \& B. L. Baker. 1950. Proc. Soc. Exptl. Biol. Med. 75: 361.

14. Holmgren, H., \& O. Wilander. 1937. Jahrb. i. Morph. u. mikr. Anat. 42: 242.

15. Kelsall, M. A., \& E. D. CrabB. 1952. Science. 115: 123.

16. Lison, L. 1936. Histochimie animale. Gauthier-Villars. Paris.

17. Paff, G. H., \& F. Bloom. 1949. Anat. Record. 104: 45.

18. Smith, R. W., R. R. Margulis, M. J. Brfinnan, \& R. W. Monto. 1950. Science. 112: 295 .

19. Sylvén, B. 1941. Acta Chir. Scand. 86(66).

20. WebB, R. L. 1931. Am. J. Anat. 49: 283.

21. Wrlander, O. 1939. Scand. Arch. Physiol. 81(15). 


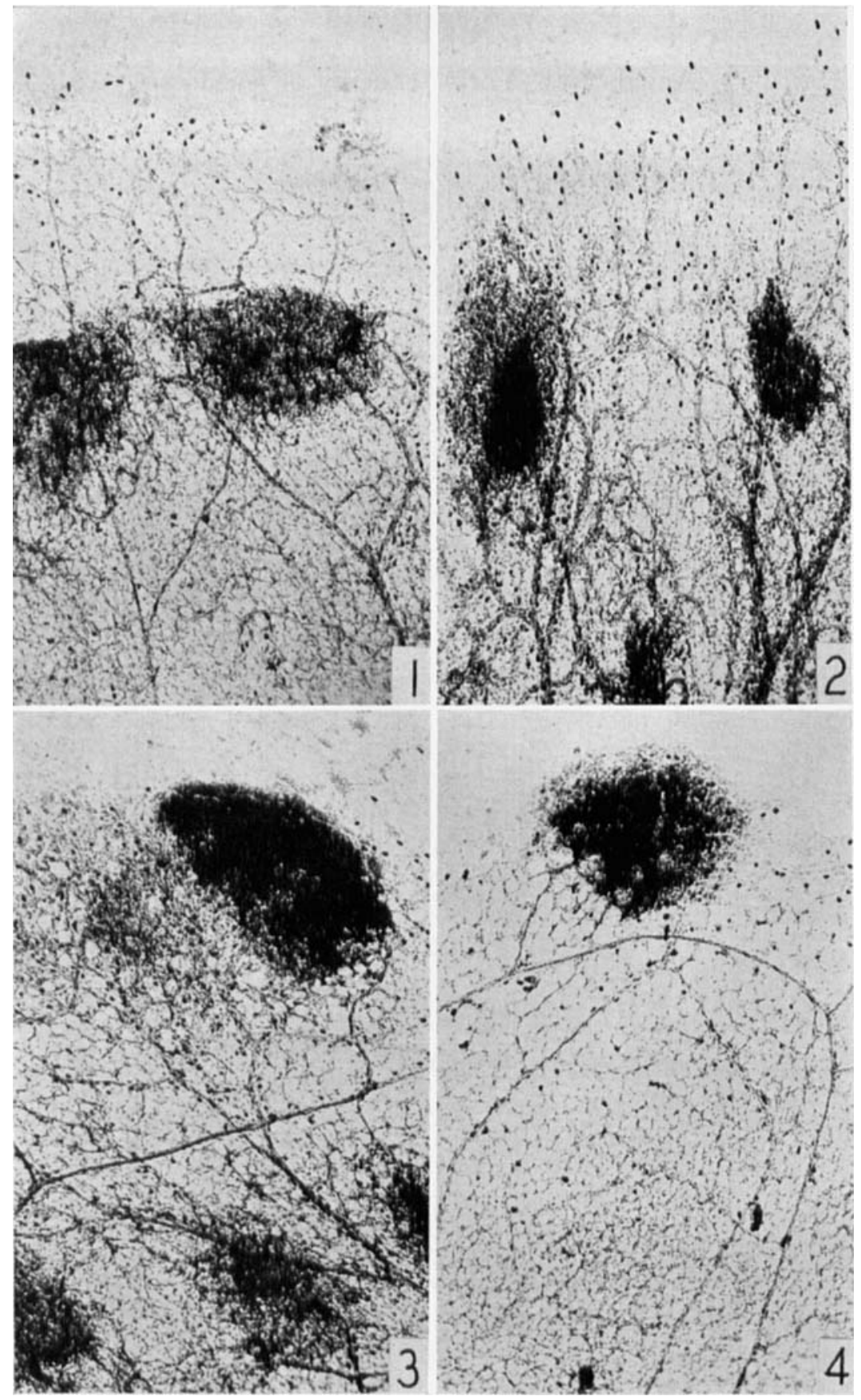

PLATE 1

FIgUre 1. Pair-fed control for specimen illustrated in FIGURe 2. Periphery of omental fat showing scattered mast cells in capillary network above, and in milk spots. Fat cells (vacuolated) are large and blood vessels narrow.

FigURE 2. Adrenalectomized for 43 days. Mast cells are more concentrated in capillary network and in the denser milk spots. Fat is reduced and blood vessels are wider.

Figure 3. Pair-fed control for specimen illustrated in FIGURE 4. Numerous mast cells are present at the edge of the fat.

Figure 4. Three mg. of hydrocortisone daily for 10 days. Mast cells are less concentrated, milk spots less frequent. The greater deposition of fat is accompanied by narrower blood vessels. 

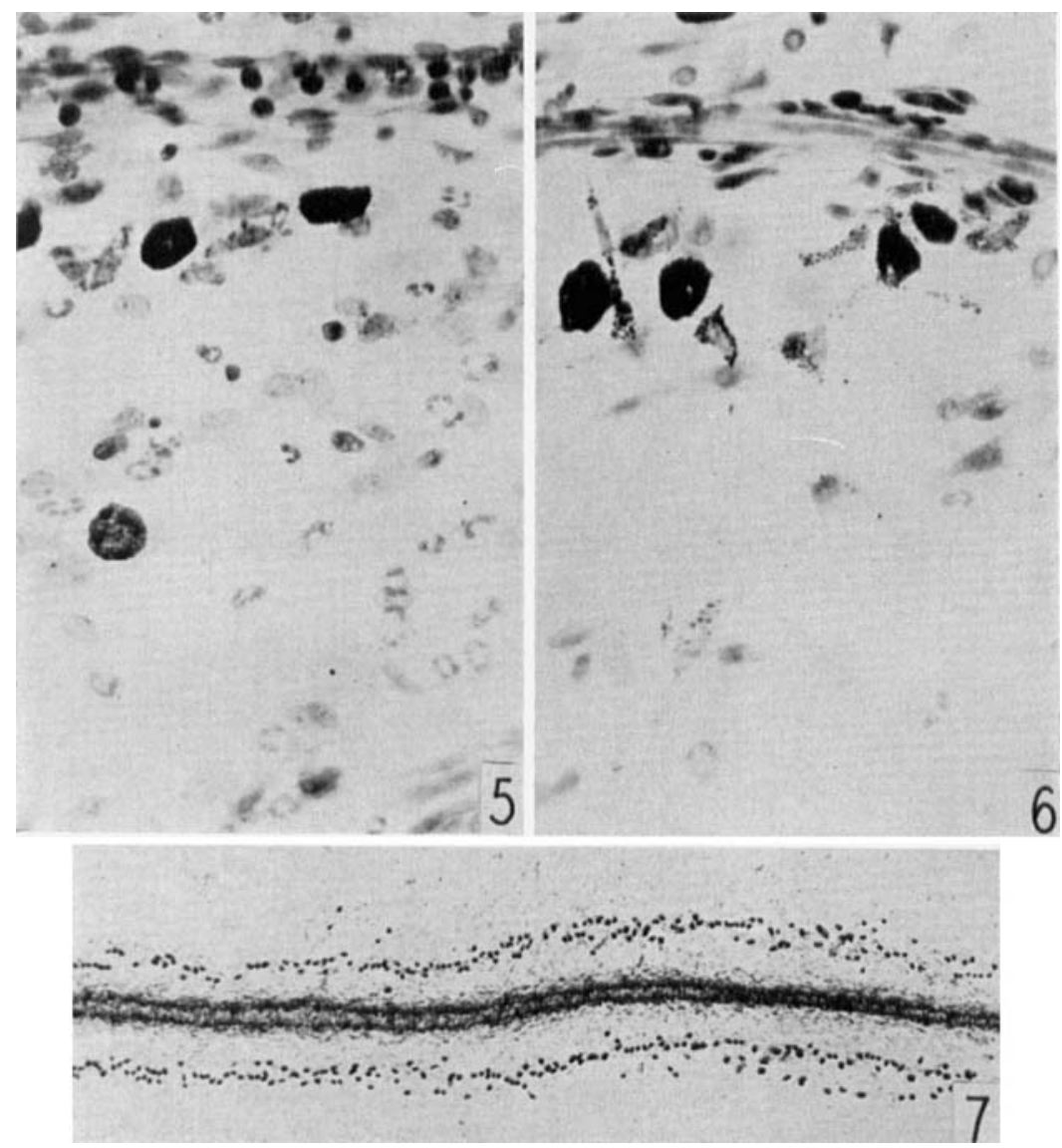

Plate 2

Figure 5. Adrenalectomy, 5 per cent peptone intra-peritoneally, control for Figure 6. A slightly congested capillary is at the top. Paravascular mast cells below it have given up some granules to intervening clasmatocytes. Polymorphonuclear leucocytes are frequent.

Figure 6 . Treatment as for FIGURE 5 except cortisone given subcutaneously. The capillary is less congested and fewer leucocytes are present in the connective tissue. Paravascular clasmatocytes have taken up mast-cell granules.

FrGURe 7. Accumulation of mast cells around a small artery, 41 days after adrenalectomy. 